Int. J. Dev. Biol. 54: 525-530 (2010)

doi: $10.1387 / \mathrm{ijdb} .082760 \mathrm{db}$

\title{
The surface area of the placenta and hypertension in the offspring in later life
}

\author{
DAVID J.P. BARKER*,1,2, KENT L. THORNBURG ${ }^{2}$, CLIVE OSMOND ${ }^{1}$, EERO KAJANTIE ${ }^{3,4}$ \\ and JOHAN G. ERIKSSON ${ }^{3,5-8}$

\begin{abstract}
${ }^{1}$ MRC Epidemiology Resource Centre (University of Southampton), Southampton General Hospital, ${ }^{4}$ Hospital for Children and Adolescents, Helsinki University Central Hospital, Helsinki, Finland,

${ }^{5}$ University of Helsinki, Department of General Practice and Primary Health Care, Helsinginyliopisto, Finland, ${ }^{6}$ Vasa Central Hospital, Vasa, Finland, ${ }^{7}$ Folkhälsan Research Centre, Helsinki, Helsingfors Universitet, Finland and ${ }^{8}$ Unit of General Practice, Helsinki University Central Hospital, Finland
\end{abstract} \\ Southampton, UK, ${ }^{2}$ Heart Research Center, Oregon Health and Science University, Portland, OR, USA, \\ ${ }^{3}$ National Institute for Health and Welfare, Department of Chronic Disease Prevention, Helsinki, Finland,
}

\begin{abstract}
Hypertension is more common among people who had low birthweight. Birthweight depends on the mother's body size and on the growth of the placenta. We studied a group of 2003 subjects, of whom 644 were being treated for hypertension. They were born during 1934-44 in a hospital that kept detailed records of maternal and placental size. Hypertension was associated with reduced placental weight and surface area. These associations were strongest in the offspring of mothers with below average height or low socioeconomic status. In people whose mothers had below average height $(160 \mathrm{~cm})$ the prevalence of hypertension fell from $38 \%$ if the placental area was $200 \mathrm{~cm}^{2}$ or less to $21 \%$ if the area was more than $320 \mathrm{~cm}^{2}(p=0.0007)$. In the offspring of tall, middle class mothers, who were likely to have been the best nourished, hypertension was predicted by large placental weight in relation to birthweight. The odds ratio rose from 1.0 if the ratio of placental weight to birthweight was 0.17 or less to 1.9 (95\% confidence interval 0.8 to 5.0 ) if the ratio was more than 0.21 ( $p$ for trend $=0.03$ ). We conclude that the effects of placental area on hypertension depend on the mother's nutritional state. Poor maternal nutrition may compound the adverse effects of small placental size. In better-nourished mothers the placental surface may expand to compensate for fetal undernutrition. Growth along the minor axis of the surface may be more nutritionally sensitive than growth along the major axis.
\end{abstract}

KEY WORDS: placental area, compensatory expansion, hypertension

\section{Introduction}

People who had low birthweight, although born at term, are at increased risk of developing hypertension in later life (Barker et al., 1990; Campbell et al., 1996; Eriksson et al., 2000). The associations between birthweight and later hypertension are graded and extend across the whole normal range. For example, eight pound babies are at lower risk than seven pound babies. These associations are thought to reflect fetal programming, the process through which fetal malnutrition and consequent small body size at birth leads to lifelong changes in the body's organs and systems in ways that lead to disease in later life. Fetal growth depends upon nutrition which is determined by the mother's nutritional stores and metabolism and by the placenta's ability to transport nutrients from mother to fetus (Harding 2001).

The information which links the placenta directly to disease in adult life is based on placental weight which is routinely measured at birth in many hospitals. The weight of the placenta at birth is correlated with the weight of the baby and, like birthweight, placental weight increases with gestation. Placental weight does not describe thickness or surface area. In order to increase the surface for nutrient and oxygen exchange the placenta can increase the surface area of villi, or invade the maternal spiral

Abbreviations used in this paper: OR, odds ratio. *Address correspondence to: David J.P. Barker. Heart Research Center, L464, Oregon Health and Science University, 3181 SW Sam Jackson Park Road,
Portland, OR 97239, USA. Fax: +1-503-494-8550. e-mail: djpbarker@gmail.com 
arteries more deeply, or expand its invasion across the surface of the uterine lining. The long-term consequences may be different. It is possible to estimate placental surface area and examine its long-term consequences in the Helsinki Birth Cohort, which comprises 13,345 people born in the city during 1934-44 (Barker et al., 2005). The birth records of each subject include not only placental weight but also two measures of the diameter of the placental surface, a maximal diameter and a lesser diameter bisecting it at right angles. In those days it was recognized that the placental surface was more oval than circular and two diameters were therefore routinely recorded. These two diameters enable the surface area of the placenta to be estimated and we present analyses of its relationship with hypertension in the offspring sixty years later.

Placental weight has been found to be associated with the later risk of hypertension (Barker et al., 1990; Campbell et al., 1996; Eriksson et al., 2000). Associations with low placental weight (Campbell et al., 1996; Eriksson et al., 2000) and with high placental weight in relation to birthweight have been reported (Barker et al., 1990; Eriksson et al., 2000). Other studies have found no associations (Whincup et al., 1995). Similarly placental weight has inconsistent associations with blood pressure levels in children. There are reported associations between increased levels with low placental weight, and with high placental weight in relation to birthweight (Moore et al., 1996; Taylor et al., 1997). These different associations could reflect different placental responses to fetal undernutrition occurring at different stages of gestation. If ewes are undernourished in mid-pregnancy, the placenta may enlarge its surface area to extract more nutrients from the mother (McCrabb et al., 1991; McCrabb et al., 1992). This only occurs, however, in ewes that were well nourished at the time of conception. The long-term effects of placental size on hypertension therefore need to be examined within subgroups defined by maternal nutrition before and during pregnancy.

Fetal nutrition depends on the mother's nutrient stores and metabolism as well as on her daily intake of food. In the Helsinki birth cohort, mother's height was recorded; this serves as a marker of her lifetime nutrition. There were also food shortages before and during the Second World War, the time when our subjects were born (Pesonen et al., 2007). These may have been more severe in families of low socio-economic status, and we used the family's socio-economic status as a marker of mother's food intake during pregnancy. We present analyses of the relationship between placental surface area and later hypertension within subgroups defined by the mother's height and socioeconomic status.

\section{Results}

\section{Placental area and thickness}

The mean age of the 2003 subjects examined at the clinic (928 men and 1075 women) was 62 years (range 57 to 70 years). 644 subjects, 310 men and 334 women, were already diagnosed as having hypertension, giving a prevalence of 33 percent in men and 31 percent in women. Placental weight was recorded for all except two of the subjects and the placental diameters for all except eight subjects. The mean maximal diameter was $2.4 \mathrm{cms}$ greater than the mean lesser diameter.

Table 1 compares the mean birthweights, ponderal indices (birth weight / length ${ }^{3}$ ) and placental measurements of people with hypertension with those for the other subjects. Hypertension was associated with reductions in birthweight, ponderal index, placental weight, area and the two diameters. We calculated odds ratios for hypertension according to placental size. Table 2 shows that the odds ratios increased as placental weight, area and the two diameters decreased. These trends were little changed by adjustment for the length of gestation.

\section{Mother's height and socio-economic status}

We examined interactions between the effects of placental size and our two markers of maternal nutrition, mother's height and socio-economic status. We divided the subjects into two groups around the median mother's height $(160 \mathrm{~cm})$, as in previous analyses (Forsen et al., 1997). Table 3 shows that the trends in the prevalence of hypertension with placental size were confined to people whose mothers were $160 \mathrm{~cm}$ or less in height. Figure 1 illustrates this, showing that while in people with short mothers the prevalence fell progressively with increasing placental area, in people with tall mothers the association was U-shaped. There was a significant interaction between the effects of mother's height and both area and the lesser placental diameter but there was no similar interaction with the maximal diameter, although the values of the two diameters were highly correlated (correlation coefficient $=0.63$ ). We divided mother's height into five equal groups, -155, -158, -161, -164, >164cm. The trends in hypertension with placental area and lesser diameter were present up to $161 \mathrm{~cm}$ and absent at greater heights. Hypertension was not associated with mothers' age or parity.

We divided the subjects into three groups according to the mother's socio-economic status, upper-middle class, lower middle class and lower class. Lower placental weight, area, lesser diameter and maximal diameter were only related to hypertension in people born into the families of manual workers ( $p$ for trend $<0.0001,0.003,0.002$ and 0.02 ). There were significant interactions between the effects of mother's socio-economic status and placental weight ( $p$ for interaction $=0.05)$, placental area $(p=0.04)$ and the lesser diameter $(p=0.008)$, but not with the maximal

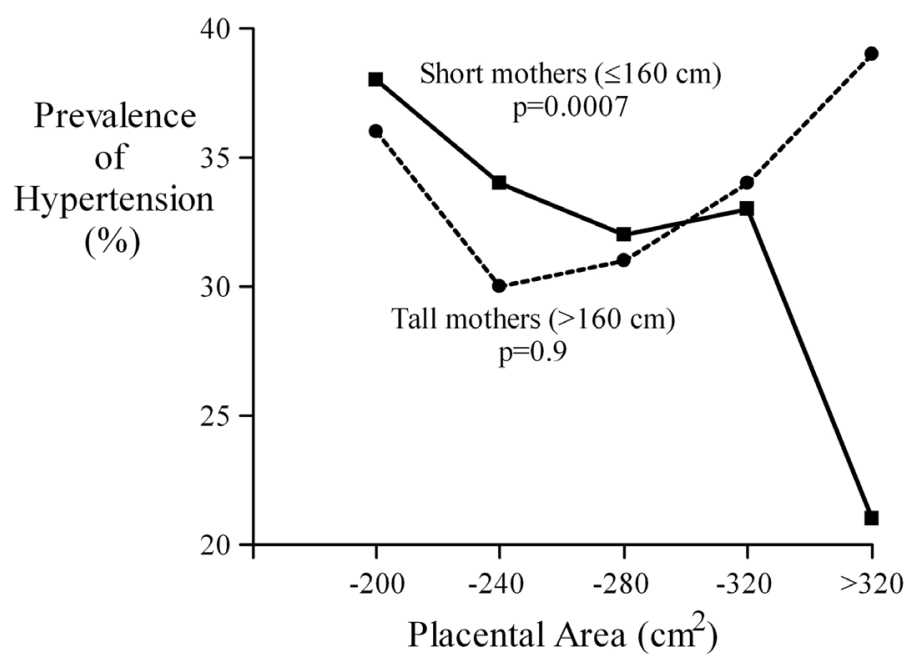

Fig. 1. Prevalence of hypertension according to placental area in the offspring of short and tall mothers. 
TABLE 1

MEAN VALUES OF BODY SIZE AT BIRTH AND PLACENTAL SIZE IN PEOPLE WITH DIAGNOSED HYPERTENSION

\begin{tabular}{|c|c|c|c|c|c|}
\hline \multirow[b]{2}{*}{ Measurement } & \multicolumn{3}{|c|}{ Diagnosed Hypertension $(n=644)$} & \multicolumn{2}{|c|}{ Other $(n=1357)$} \\
\hline & Mean & SD & $\begin{array}{c}p \text { for } \\
\text { difference }\end{array}$ & Mean & SD \\
\hline \multicolumn{6}{|l|}{ Body size at birth } \\
\hline Birthweight (g) & 3350 & 490 & $<0.001$ & 3437 & 481 \\
\hline Ponderal index $\left(\mathrm{g} / \mathrm{cm}^{3}\right)$ & 26.5 & 2.1 & 0.003 & 26.7 & 2.3 \\
\hline \multicolumn{6}{|l|}{ Placental size } \\
\hline Weight (g) & 637 & 118 & $<0.001$ & 654 & 123 \\
\hline Area $\left(\mathrm{cm}^{2}\right)$ & 256 & 55 & 0.009 & 261 & 60 \\
\hline Maximal diameter $(\mathrm{cm})$ & 19.2 & 2.1 & 0.02 & 19.4 & 2.3 \\
\hline Lesser diameter $(\mathrm{cm})$ & 16.8 & 2.2 & 0.02 & 17.0 & 2.2 \\
\hline Thickness $(\mathrm{cm})$ & 2.56 & 0.56 & 0.5 & 2.58 & 0.55 \\
\hline
\end{tabular}

*adjusted for age, sex and adult waist circumference

diameter $(p=0.3)$. Table 4 shows the trends in prevalence of hypertension with the lesser diameter. In addition to the increase in prevalence with a shorter lesser diameter, seen in people born into lower class families, there was an opposing trend in people born into upper middle class families.

We combined the two middle class groups and examined the trends in hypertension among people born to tall or short mothers, using the median height, and people born into middle or lower class families. Table 5 shows that, among people born to short mothers, odds ratios for hypertension fell with increasing placental weight in both social class groups. There was a similar trend in people born to tall mothers in lower social class families, but there was no trend among people born to tall mothers in middle class families. In this latter group, however, odds ratios for hypertension rose as the placental to birth weight ratio increased (Table 5). In a simultaneous regression odds ratios rose with increasing placental weight $(p=0.04)$ but fell with increasing birthweight ( $p=0.003)$. In a similar simultaneous regression, odds ratios rose with an increase in the lesser diameter $(p=0.04)$, but fell with increasing birthweight $(p=0.07)$. There was no corresponding trend with the maximal diameter $(p=0.3)$ and the trend with placental area was of borderline statistical significance $(p=0.09)$. We examined the effects of body size at birth in people born to tall, middle class mothers. Hypertension was associated with high birthweight $(p=0.03)$ and high body mass index $(p=0.02)$. It was not associated with any other measurements of body size.

\section{Discussion}

This study adds to the body of evidence suggesting that hypertension is initiated by fetal malnutrition and the placental responses that accompany it. The study shows for the first time that the effects of placental size on hypertension depend on the mother's body size and socioeconomic status, two markers of her nutritional state. We found that hypertension was associated with both reduced placental weight and with increased placental weight in relation to birthweight. Both of these associations have been found before (Barker et al., 1990; Campbell et al., 1996; Eriksson et al., 2000). The association with low placental weight was accompanied by reduced placental area but not reduced thickness. This association with low surface area has not been

TABLE 2

\section{ODDS RATIOS (95\% CONFIDENCE INTERVALS) FOR HYPERTENSION ACCORDING TO PLACENTAL WEIGHT, AREA AND DIAMETERS}

\begin{tabular}{|c|c|c|c|c|}
\hline $\begin{array}{c}\text { Placental } \\
\text { measurements } \\
\text { measurement }\end{array}$ & $\begin{array}{c}\text { No. with } \\
\text { hypertension }\end{array}$ & No. of subjects & Odds Ratio & $95 \% \mathrm{Cl}$ \\
\hline \multicolumn{5}{|l|}{ Weight (g) } \\
\hline-550 & 179 & 475 & 1.8 & 1.3 to 2.4 \\
\hline-650 & 201 & 655 & 1.3 & 1.0 to 1.8 \\
\hline-750 & 166 & 523 & 1.3 & 0.9 to 1.7 \\
\hline$>750$ & 97 & 346 & 1.0 & baseline \\
\hline$p$ for trend $d^{*}$ & & & $<0.001$ & \\
\hline \multicolumn{5}{|l|}{ Area $\left(\mathrm{cm}^{2}\right)$} \\
\hline-200 & 82 & 232 & 1.5 & 1.0 to 2.2 \\
\hline-240 & 171 & 537 & 1.2 & 0.8 to 1.7 \\
\hline-280 & 158 & 498 & 1.2 & 0.8 to 1.6 \\
\hline-320 & 152 & 468 & 1.1 & 0.8 to 1.6 \\
\hline$>320$ & 75 & 258 & 1.0 & baseline \\
\hline$p$ for trend $d^{*}$ & & & 0.009 & \\
\hline \multicolumn{5}{|c|}{ Lesser diameter $(\mathbf{c m})$} \\
\hline-15 & 175 & 508 & 1.4 & 1.1 to 1.9 \\
\hline-16 & 103 & 349 & 1.1 & 0.8 to 1.5 \\
\hline-17 & 101 & 327 & 1.2 & 0.9 to 1.7 \\
\hline-18 & 140 & 409 & 1.3 & 0.9 to 1.8 \\
\hline$>18$ & 119 & 400 & 1.0 & baseline \\
\hline$p$ for trend ${ }^{*}$ & & & 0.02 & \\
\hline \multicolumn{5}{|c|}{ Maximal diameter $(\mathrm{cm})$} \\
\hline-15 & 115 & 332 & 1.3 & 0.9 to 1.8 \\
\hline-16 & 135 & 394 & 1.3 & 0.9 to 1.7 \\
\hline-17 & 79 & 296 & 0.8 & 0.6 to 1.2 \\
\hline-18 & 175 & 535 & 1.1 & 0.8 to 1.4 \\
\hline$>18$ & 134 & 436 & 1.0 & baseline \\
\hline$p$ for trend ${ }^{*}$ & & & 0.02 & \\
\hline
\end{tabular}

*adjusted for age, sex and adult waist circumference

TABLE 3

PREVALENCE (\%) OF HYPERTENSION, ADJUSTED FOR AGE AND SEX, ACCORDING TO PLACENTAL AREA AND MOTHER'S HEIGHT

\begin{tabular}{|c|c|c|c|c|}
\hline \multirow[b]{3}{*}{ Placental Measurement } & \multicolumn{4}{|c|}{ Mother's height (cm) } \\
\hline & \multicolumn{2}{|c|}{$\leq 160$} & \multicolumn{2}{|c|}{$>160$} \\
\hline & Prevalence & Cases & Prevalence & Cases \\
\hline \multicolumn{5}{|l|}{ Weight (g) } \\
\hline-550 & 39 & 100 & 39 & 59 \\
\hline-650 & 31 & 114 & 32 & 69 \\
\hline-750 & 33 & 84 & 30 & 63 \\
\hline$>750$ & 24 & 39 & 34 & 52 \\
\hline$p$ for trend* & $<0.0001$ & & 0.4 & \\
\hline$p$ for interaction & 0.10 & & & \\
\hline \multicolumn{5}{|l|}{ Area $\left(\mathrm{cm}^{2}\right)$} \\
\hline-200 & 38 & 47 & 36 & 27 \\
\hline-240 & 34 & 102 & 30 & 52 \\
\hline-280 & 32 & 85 & 31 & 60 \\
\hline-320 & 33 & 74 & 34 & 62 \\
\hline$>320$ & 21 & 26 & 39 & 41 \\
\hline$p$ for trend & 0.0007 & & 0.88 & \\
\hline$p$ for interaction & 0.02 & & & \\
\hline \multicolumn{5}{|l|}{ Lesser Diameter (cm) } \\
\hline-15 & 37 & 105 & 33 & 56 \\
\hline-16 & 30 & 55 & 30 & 37 \\
\hline-17 & 33 & 60 & 27 & 32 \\
\hline-18 & 33 & 67 & 37 & 59 \\
\hline$>18$ & 24 & 47 & 37 & 58 \\
\hline$p$ for trend* & 0.0009 & & 0.95 & \\
\hline$p$ for interaction & 0.002 & & & \\
\hline \multicolumn{5}{|l|}{ Maximal Diameter (cm) } \\
\hline-15 & 36 & 67 & 36 & 33 \\
\hline-16 & 35 & 77 & 35 & 46 \\
\hline-17 & 26 & 42 & 26 & 28 \\
\hline-18 & 35 & 91 & 32 & 70 \\
\hline$>18$ & 27 & 57 & 36 & 65 \\
\hline$p$ for trend ${ }^{*}$ & 0.01 & & 0.6 & \\
\hline$p$ for interaction & 0.2 & & & \\
\hline
\end{tabular}

*adjusted for age, sex and adult waist circumference 
TABLE 4

PREVALENCE (\%) OF HYPERTENSION, ADJUSTED FOR AGE AND SEX, ACCORDING TO THE LESSER PLACENTAL DIAMETER AND THE MOTHER'S SOCIAL CLASS

\begin{tabular}{cccccccc} 
& \multicolumn{8}{c}{ Mother's social class } \\
\cline { 2 - 7 } $\begin{array}{c}\text { Lesser placental } \\
\text { diameter }(\mathbf{c m})\end{array}$ & \multicolumn{2}{c}{ Upper middle } & \multicolumn{2}{c}{ Lower middle } & \multicolumn{2}{c}{ Lower } & p for \\
\cline { 2 - 7 } & Prevalence & Cases & Prevalence & Cases & Prevalence & Cases & trend $^{\star}$ \\
\hline-15 & 18 & 10 & 29 & 28 & 39 & 131 & 0.001 \\
-18 & 21 & 25 & 30 & 62 & 34 & 244 & 0.003 \\
$>18$ & 36 & 13 & 33 & 24 & 28 & 78 & 0.34 \\
p for trend & 0.06 & & 0.70 & & 0.004 & & \\
\hline
\end{tabular}

*adjusted for age, sex and adult waist circumference

previously described. The area of the placenta reflects its spread across the inner wall of the uterus, while its thickness represents the volume of endocrine and nutrient exchange tissue. It is not known how closely the surface area of the placenta, measured by two diameters, reflects the total surface area of the trophoblast. We found that, in the offspring of mothers who were tall and middle class, and therefore likely to have been the best nourished, hypertension was predicted by large placental weight in relation to birthweight. This association has been found before (Barker et al., 1990; Eriksson et al., 2000), but it has not previously been linked to the mother's height and socio-economic status.

In humans placental size is known to respond to maternal influences. Maternal anaemia and high maternal body mass index are associated with a high ratio of placental weight to birth weight (Godfrey etal., 1991). Maternal smoking reduces placental weight but increases the ratio of placental weight to birth weight (Godfrey et al., 1991). The mechanisms that mediate these responses, which show the plasticity of the placenta, are largely unknown, and the effects of these responses on placental area and thickness have not been documented (Jansson and Powell 2007). The plasticity of placental size may explain why some studies have failed to show any association between placental size and later increased blood pressure or clinical hypertension. In our study there was no overall effect of placental size on hypertension within the offspring of tall mothers (Table 3). When, however, these offspring were subdivided by the family's socio-economic status opposing trends were revealed (Table 5). In lower social class families the prevalence of hypertension increased as placental weight fell. In middle class families, hypertension increased as the ratio of placental weight to birthweight increased. The different trends in these two groups oppose each other sufficiently that when they are combined, there is no trend in hypertension with placental weight (Table 3).

\section{Small placental area}

The association between hypertension and small placental size (Tables 1,2) suggests that the disorder can be initiated through restricted placental growth in the weeks after implantation, resulting in a reduced placental area that limits transfer of nutrients to the baby. The strong effects of reduction in placental size in people born to short mothers suggest a link with the lifetime nutrition of the mother. Short maternal stature is a product of poor fetal or childhood nutrition, or recurrent exposure to infections, though there are also genetic influences (Tanner 1989). We speculate that some aspect of poor nutrition among girls prejudices their ability to nourish their babies when they later become pregnant, and exacerbates the effects of restricted placental growth. These effects may be further exacerbated by poor maternal nutrition during pregnancy. There were food shortages in Helsinki before and during the Second World War, the time when our subjects were born (Pesonen et al., 2007). These may have been more severe in families of low socio-economic status, and we found that the effects of small placental size were stronger in people born into lower class families (Table 4).

\section{Large placental area}

In contrast to these associations with small placental size, high values for placental weight, and a large lesser diameter, were related to hypertension in people whose mothers were tall and middle class. In these people hypertension was associated with large placental size in relation to birthweight. This association suggests that hypertension can be initiated through placental overgrowth as well as through impaired placentation. Observations in sheep show that in response to undernutrition a fetus is able to extend the area of the placenta by expanding the individual cotyledons (McCrabb et al., 1991; McCrabb et al., 1992). This increases the area available for nutrient and oxygen exchange and paradoxically leads to large body size at birth. This response to undernutrition only occurs in ewes that were well nourished before conception (McCrabb et al., 1992). In our study, tall mothers in middle class families are likely to have been the best nourished both in childhood and in early adult life. During preg-

TABLE 5

ODDS RATIOS (OR) FOR HYPERTENSION ACCORDING TO PLACENTAL WEIGHT, AND THE RATIO OF PLACENTAL WEIGHT TO BIRTHWEIGHT, IN GROUPS DEFINED BY MOTHER'S HEIGHT AND SOCIAL CLASS

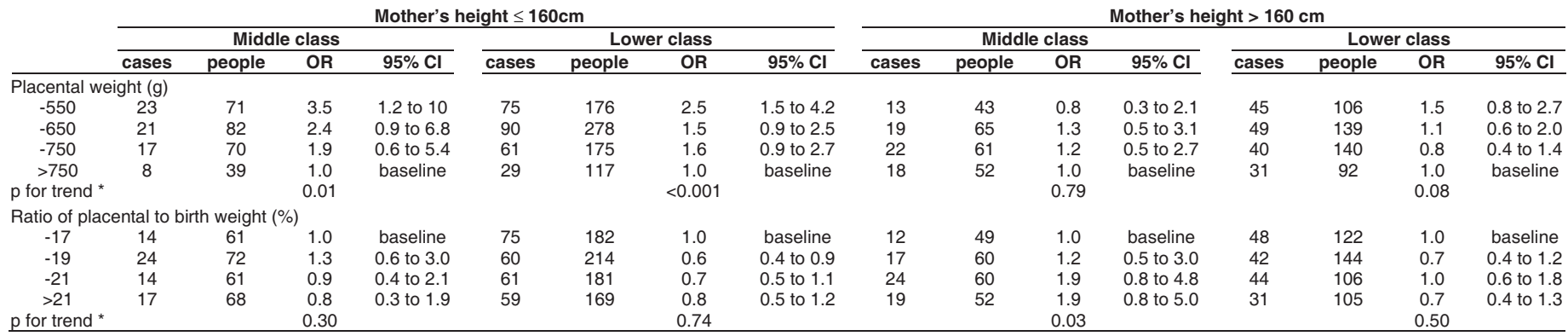

*adjusted for age, sex and adult waist circumference 
nancy, however, they would have been subject to the food scarcities around the time of the Second World War. We speculate that their fetuses responded to this by expansion of the placental surface. The ability to expand its surface area may be part of the human placenta's responses to malnutrition that only operates in mothers who were well nourished before conception. This has never been investigated. Among the offspring of tall, middle class mothers hypertension was associated with high birthweight rather than with low birthweight. This suggests that, as in sheep, placental enlargement in response to fetoplacental malnutrition, leads to increased body size at birth. Studies which include large numbers of tall middle class mothers may fail to demonstrate the well known association between low birthweight and later hypertension

\section{Placental diameters}

Textbooks of midwifery written in the period between the two world wars describe the placental surface as either "oval" or "round", although it was recognised that other, deviant shapes occurred (Anderson 1930; Hinselmann 1925). The average diameter was given as 16 to $20 \mathrm{cms}$, which corresponds to the diameters in our study. In Helsinki at that time two diameters, one the maximal one and the other bisecting it at right angles, were routinely measured to describe the extent to which the surface was more oval than round. Although the size of the two diameters is highly correlated, and they differ on average by only $2.4 \mathrm{cms}$, we found that the lesser diameter was more closely associated with the later development of hypertension. While the interaction between mother's height and the effects of placental area (Fig. 1) was reflected in a similar interaction with the lesser placental diameter (Table 3), there was no interaction between mother's height and the maximal diameter. An interpretation of these findings is that the growth of the lesser diameter is more nutritionally sensitive than the growth of the maximal diameter.

\section{Body size and nephron number}

In our study people who had hypertension had low birthweight and were thin, two markers of fetal undernutrition. In both experimental animals and in humans undernourished fetuses restrict renal growth (Barker et al., 2006; Brenner and Chertow 1993; Keller et al., 2003). Kidney development may have a low priority during intrauterine development because the mother's kidney functions for both mother and baby. In humans there is a critical period of nephrogenesis around 34 weeks and after birth no further nephrons develop (Barker et al., 2006). Low birthweight is known to be associated with reduced nephron number. Reduced nephron number may lead to glomerular hyper-perfusion, sclerosis and premature nephron death. This has been proposed as one of the mechanisms underlying the early origins of hypertension (Brenner and Chertow 1993). The placenta could contribute to the reduction in nephron numbers, either because a small placenta limits nutrient transfer or because a large placenta diverts nutrients to itself (Harding 2001). Differences in placental structure could also contribute to other mechanisms of hypertension, such as impaired vascular structure and endothelial dysfunction (Barker etal., 2006).

\section{Limitations of the study}

The placental measurements in our study were made during routine obstetric practice 70 years ago. The mean placental weight was above the median recorded in a recent series of deliveries in Europe (Burkhardt et al., 2006). Routine measurements of the placental diameters ceased in Helsinki in the 1970s. We have discussed the simple procedures that were used with people who worked as midwives at that time. There were no routine checks of the quality of the measurements, just as there are no routine checks of the quality of blood pressure and other measurements made in current clinical practice. Measurement errors would tend to diminish the associations between the placental diameters and hypertension in later life. Our study was restricted to people who had visited child welfare clinics. Although the majority of children visited these clinics, which were free, the visits were voluntary. The people in our study may not be representative of all people now living in Helsinki, although at birth their social class distribution was similar to that in the city as a whole.

\section{Conclusion}

We found that hypertension was associated with reduced placental weight and area but not with reduced thickness. We showed for the first time that the effects of placental size on hypertension depend on the mother's height and socio-economic status. We found that, in the offspring of mothers who were short or of low socio-economic status, hypertension was associated with low placental weight and area. In the offspring of mothers who were likely to have been the best nourished, being tall and middle class, hypertension was predicted by large placental size in relation to birthweight.

\section{Materials and Methods}

The cohort comprised men and women who were born between 1934 and 1944 in the University Central Hospital and who visited infant welfare clinics in the city. Details of the birth records, child welfare clinic records and school health records have been previously described (Barker et al., 2005). The birth records included the mother's height, age and parity. The records also included the weight of the placenta, together with the maximal diameter of the surface and a lesser diameter bisecting it at right angles. The measurements were made because it was recognised that the placental surface is more oval than circular and the two diameters were used to describe this. Assuming an elliptical surface, we estimated the surface area of the placenta as maximal $\times$ lesser diameter $\times \pi / 4$. Assuming a constant density we estimated the thickness of the placenta as weight divided by area.

We identified 8760 men and women, born as singletons, who were living in Finland in 1971, when a unique identification number was allocated to each member of the Finnish population. We used random number tables to select a sample of people within the cohort who were still alive and living in Finland. In order to achieve a sample size in excess of 2000 people we selected 2902 subjects and invited them to a clinic. 2003 visited the clinic, which was held at the National Public Health Institute in Helsinki. The procedures used at the clinic have been described (Barker et al., 2005). 644 of the men and women had been previously diagnosed as having hypertension and had been prescribed medication (Eriksson et al., 2007). The birth records included data on the father's occupation, grouped into upper and lower middle class and manual workers, based on a classification from Statistics Finland. We used the father's occupation to define the mother's social class. Written informed consent was obtained from each subject before any procedures were carried out. The Ethics Committee at the National Public Health Institute, Finland approved the study. 


\section{Statistical Methods}

We assessed associations with the prevalence of diagnosed hypertension using multiple logistic regression, always adjusted for age, sex and waist circumference as in our previous analyses. We only used models in which a single placental parameter is entered at a time. The prevalence of hypertension increased with age and was higher in men. Placental size differed in boys and girls. The measurements of placental and maternal size were analysed as continuous variables although presented in the tables as groups. Tests for interaction used the product of the variables being studied.

\section{Funding sources}

This study was supported by the British Heart Foundation, the Academy of Finland, the Paivikki and Sakari Sohlberg Foundation, the Finnish Diabetes Research Foundation, the Finnish Foundation for Cardiovascular Research, the Finnish Medical Society Duodecim, Yrjo Jahnsson Foundation, and Finska Lakaresällskapet, the M. Lowell Edwards Endowment.

\section{References}

ANDERSON MC(1930). Lessons in midwifery for nurses and midwifes. A \& C Black; London.

BARKER DJP, BULL AR, OSMOND C, SIMMONDS SJ (1990). Fetal and placental size and risk of hypertension in adult life. Br Med J301: 259-262.

BARKER DJP, OSMOND C, FORSENTJ, KAJANTIE E, ERIKSSON JG (2005). Trajectories of growth among children who have coronary events as adults. New Eng J Med 353: 1802-1809.

BARKER DJP, BAGBY S, HANSON MA (2006). Mechanisms of disease: in utero programming in the pathogenesis of hypertension. Nature Clin Pract Nephro/2: 700-707.

BRENNER BM, CHERTOW GM (1993). Congenital oligonephropathy: an inborn cause of adult hypertension and progressive renal injury? Curr Opin Neph Hypertens 2: 691-695.

BURKHARDT T, SCHAFFER L, SCHNEIDER C, ZIMMERMAN R, KURMANAVICIUS J (2006). Reference values for the weight of freshly delivered term placentas and for placental weight - birth weight ratios. European $J$ Obstet Gynaecol128: 248-252.

CAMPBELL DM, HALL MH, BARKER DJP, CROSS J, SHIELL AW, GODFREY KM (1996). Diet in pregnancy and the offspring's blood pressure 40 years later. Brit J Obstet Gynaeco/103: 273-280.
ERIKSSON JG, FORSEN TJ,TUOMILHETO J, OSMOND C, BARKER DJP (2000). Fetal and childhood growth and hypertension in adult life. Hypertension 36: 790-794.

ERIKSSON JG, KAJANTIE E, FORSEN TJ, OSMOND C, BARKER DJP (2007). Childhood growth and hypertension in later life. Hypertension 49: 1415-1421.

FORSENTJ, ERIKSSON JG, TUOMILHETO J, TERAMO K, OSMOND C, BARKER DJP (1997). Mother's weight in pregnancy and coronary heart disease in a cohort of Finnish men: follow up study. Br Med J315: 837-840.

GODFREY KM, REDMAN CWG, BARKER DJP, OSMOND C (1991). The effect of maternal anaemia and iron deficiency on the ratio of fetal weight to placental weight. Brit J Obstet Gynaeco/98: 886-891.

HARDING J (2001). The nutritional basis of the fetal origins of adult disease. Int $J$ Epidemio/30: 15-23.

HINSELMANN H(1925). Biologie und Pathologie des Weibes. Urban \& Schwarzenberg; Berlin.

JANSSON T, POWELL TL(2007). Role of the placenta in fetal programming: underlying mechanisms and potential interventional approaches. Clin Sci113: 1-13.

KELLER G, ZIMMER G, MALL G, RITZ E, AMMANN K (2003). Nephron number in patients with primary hypertension. New Eng J Med348: 101-108.

McCRABB GJ, EGAN AR, HOSKING BJ (1991). Maternal undernutrition during mid-pregnancy in sheep. Placental size and its relationship to calcium transfer during late pregnancy. Brit J Nutr 65: 157-168.

McCRABB GJ, EGAN AR, HOSKING BJ (1992). Maternal undernutrition during mid-pregnancy in sheep; variable effects on placental growth. J Agric Sci118: 127-132.

MOORE VM, MILLER AG, BOULTON TJ, COCKINGTON RA, CRAUG IH, MAGAREY AM, ROBINSON JS (1996). Placental weight, birth measurements, and blood pressure at age 8 years. Arch Dis Child74: 538-41.

PESONEN AK, RAIKKONEN K, HEINONEN K, KAJANTIE E, FORSEN T, ERIKSSON J (2007). Depressive symptoms in adults separated from their parents as children: a natural experiment during World War II. Am J Epidemiol. 166: 1126-1133

TANNER JM (1989). Fetus into man. $2^{\text {nd }}$ ed. Castlemead: Ware

TAYLOR SJC, WHINCUP PH, COOK DG, PAPACOSTA O, WALKER M (1997) Size at birth and blood pressure; cross sectional study in 8-11 year old children. Br Med J314: 475-480.

WHINCUP P, COOKD, PAPACOSTA O, WALKER M (1995). Birth weight and blood pressure: cross sectional and longitudinal relations in childhood. BrMed $\mathcal{3} 11$ : 773-776. 


\section{Further Related Reading, published previously in the Int. J. Dev. Biol.}

See our recent Special Issue Epigenetics \& Development edited by Saadi Khochbin and Stefan Nonchev at:

http://www.ijdb.ehu.es/web/contents.php?vol=53\&issue=2-3

See Special Issue Pattern Formation edited by Michael K. Richardson and Cheng-Ming Chuong at:

http://www.ijdb.ehu.es/web/contents.php?vol=53\&issue=5-6

Spatiotemporal expression of the selenoprotein $\mathbf{P}$ genein postimplantational mouse embryos

Se-Ra Lee, Jung-Min Yon, In-Jeoung Baek, Mi-Ra Kim, Chun-Gui Park, Beom-Jun Lee, Young-Won Yun and Sang-Yoon Nam Int. J. Dev. Biol. (2008) 52: 1005-1011

Puzzles of mammalian fertilization - and beyond

J. Michael Bedford

Int. J. Dev. Biol. (2008) 52: 415-426

An activating mutation in the PDGF receptor-beta causes abnormal morphology in the mouse placenta

Camilla Looman, Tong Sun, Yang Yu, Agata Zieba, Aive Ahgren, Ricardo Feinstein, Henrik Forsberg, Carina Hellberg, Carl-Henrik Heldin, Xiao-Qun Zhang, Karin Forsberg-Nilsson, Nelson Khoo, Reinald Fundele and Rainer Heuchel

Int. J. Dev. Biol. (2007) 51: 361-370

A simple in vivo approach to investigate invasive trophoblast cells Juan A. Arroyo, Toshihiro Konno, Darya C. Khalili and Michael J. Soares Int. J. Dev. Biol. (2005) 49: 977-980

Control of reproduction by Polycomb Group complexes in animals and plants Anne-Elisabeth Guitton and Frederic Berger

Int. J. Dev. Biol. (2005) 49: 707-716

Commitment of hematopoietic stem cells in avian and mammalian embryos: an ongoing story

Françoise Dieterlen-Lièvre

Int. J. Dev. Biol. (2005) 49: 125-130

Dynamic readjustment of parental methylation patterns of the 5'-flank of the mouse $\mathrm{H} 19$ gene during in vitro organogenesis.

L Liang, C Kanduri, M Pilartz, K Svensson, J H Song, P Wentzel, U Eriksson and R Ohlsson Int. J. Dev. Biol. (2000) 44: 785-790

Met signaling mutants as tools for developmental studies.

C Ponzetto, G Panté, C Prunotto', A leraci and F Maina

Int. J. Dev. Biol. (2000) 44: 645-653

Multiple functions of DIx genes.

G R Merlo, B Zerega, L Paleari, S Trombino, S Mantero and G Levi

Int. J. Dev. Biol. (2000) 44: 619-626

Changes in the placenta and in the rat embryo caused by the demethylating agent 5azacytidine.

M Vlahovic, F Bulic-Jakus, G Juric-Lekic, A Fucic, S Maric and D Serman

Int. J. Dev. Biol. (1999) 43: 843-846

Influence of fetal environment on kidney development.

C Merlet-Bénichou

Int. J. Dev. Biol. (1999) 43: 453-456

The human placenta becomes haemochorial at the 13th week of pregnancy.

J M Foidart, J Hustin, M Dubois and J P Schaaps

Int. J. Dev. Biol. (1992) 36: 451-453

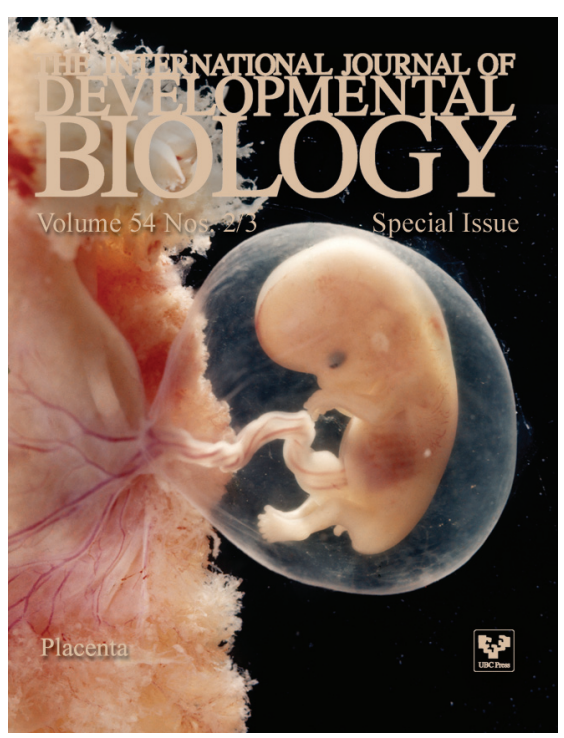

5 yr ISI Impact Factor $(2008)=3.271$

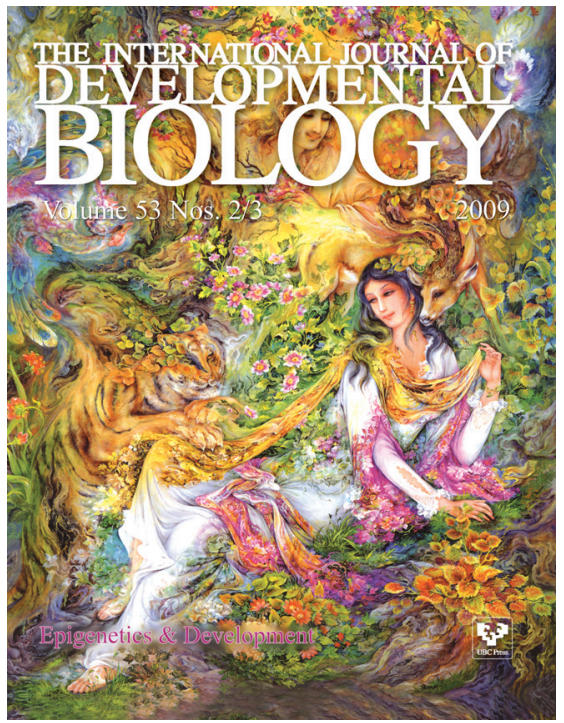

